OPEN ACCESS

Edited by:

Sherven Sharma,

VA Greater Los Angeles Healthcare System (NHA),

United States

Reviewed by:

Carlos Alfaro,

Universidad de Navarra, Spain

Per Thor Straten,

Herlev Hospital,

Denmark

*Correspondence:

Sophie Sibéril

sophie.siberi@upmc.fr

Specialty section:

This article was submitted

to Cancer Immunity and

Immunotherapy,

a section of the journal

Frontiers in Immunology

Received: 19 May 2017

Accepted: 25 July 2017

Published: 14 August 2017

Citation:

Deligne C, Milcent B, Josseaume N, Teillaud J-L and Sibéril S (2017) Impact of Depleting Therapeutic

Monoclonal Antibodies on

the Host Adaptive Immunity:

A Bonus or a Malus?

Front. Immunol. 8:950.

doi: 10.3389/fimmu.2017.00950

\section{Impact of Depleting Therapeutic Monoclonal Antibodies on the Host Adaptive Immunity: A Bonus or a Malus?}

\author{
Claire Deligne ${ }^{1,2,3,4}$, Benoît Milcent ${ }^{1,2,3}$, Nathalie Josseaume ${ }^{1,2,3}$, Jean-Luc Teillaud ${ }^{1,2,3}$ and \\ Sophie Sibéril ${ }^{1,2,3 *}$ \\ ${ }^{1}$ Cordeliers Research Center, INSERM UMR-S 1138, "Cancer, Immune Control and Escape" Laboratory, Paris, France, \\ ${ }^{2}$ Sorbonne Universities, Université Pierre et Marie Curie, UMR-S 1138, Paris, France, ${ }^{3}$ Université Paris Descartes, UMR-S \\ 1138, Paris, France, ${ }^{4}$ Kennedy Institute of Rheumatology, University of Oxford, Oxford, United Kingdom
}

Clinical responses to anti-tumor monoclonal antibody $(\mathrm{mAb})$ treatment have been regarded for many years only as a consequence of the ability of mAbs to destroy tumor cells by innate immune effector mechanisms. More recently, it has also been shown that anti-tumor antibodies can induce a long-lasting anti-tumor adaptive immunity, likely responsible for durable clinical responses, a phenomenon that has been termed the vaccinal effect of antibodies. However, some of these anti-tumor antibodies are directed against molecules expressed both by tumor cells and normal immune cells, in particular lymphocytes, and, hence, can also strongly affect the host adaptive immunity. In addition to a delayed recovery of target cells, lymphocyte depleting-mAb treatments can have dramatic consequences on the adaptive immune cell network, its rebound, and its functional capacities. Thus, in this review, we will not only discuss the mAb-induced vaccinal effect that has emerged from experimental preclinical studies and clinical trials but also the multifaceted impact of lymphocytes-depleting therapeutic antibodies on the host adaptive immunity. We will also discuss some of the molecular and cellular mechanisms of action whereby therapeutic mAbs induce a long-term protective anti-tumor effect and the relationship between the mAb-induced vaccinal effect and the immune response against self-antigens.

Keywords: adaptive immunity, antibody-induced immunogenic cell death, CD20, hematologic malignancies, immunotherapy, therapeutic monoclonal antibodies, vaccinal effect

\section{INTRODUCTION}

Immunotherapy has now gained its place among the therapeutic arsenal of cancer therapies, based on the demonstration that tumors are under the surveillance of the host immune system (1), brought by studies performed on large cohorts of cancer patients with a high incidence case $(2-4)$. In particular, monoclonal antibody $(\mathrm{mAb})$ biotherapies have shown remarkable results in a significant number of cancer patients. A first category of antibodies are directed against tumor cells. It includes antibodies directed against tumor cells belonging to the hematopoietic lineage, lymphocytes (CD20, CD52, CD38, etc.), and myeloid cells (CD30, CD33, etc.). A number of other anti-tumor antibodies are directed against molecules expressed by a large variety of cell types (HER2/ 
neu, EGFR, etc.). These antibodies are classically thought to work through a variety of mechanisms. It includes the inhibition of ligand binding to specific receptors, the blockade of receptor activation, thus interfering with signaling pathways, and/or through their ability to deplete tumor cells. Also, some antibodies block the neovasculature formation that accompanies tumor development [anti-vascular endothelium growth factor (VEGF), anti-EGFR, or anti-VEGFR2]. Moreover, another category of antibodies directed against immune checkpoint (ICP) molecules has emerged over the last decade, able to modulate the cellular and molecular microenvironment of tumors, as exemplified by the successful use of anti-CTLA- 4 or anti-PD-1 antibodies.

The capacity of anti-tumor antibodies to deplete cancer cells has been largely documented in vitro and in preclinical animal settings. Antibodies exhibiting a human IgG1 Fc region (which represents a large proportion of antibodies used for cancer treatment) trigger Fc-dependent effector mechanisms [complement-dependent cytotoxicity (CDC), antibody-dependent cell cytotoxicity (ADCC), and phagocytosis]. The activation of the classical pathway of complement through the binding of $\mathrm{Clq}$ to the Fc portion of $\mathrm{mAbs}$ and the recruitment of $\mathrm{Fc} \gamma$ receptors (Fc $\gamma$ Rs) expressed by NK cells, neutrophils, monocytes, and macrophages lead to the formation and/or the release of effector molecules (membrane attack complex made of C5b-C9, perforin and granzymes, TNF- $\alpha$, Reactive Oxygen Intermediates, etc.) that induce cell death. This has stimulated a lot of engineering efforts over the last 20 years, aimed at boosting effector mechanisms relying on the Fc region of $\operatorname{IgG}(5,6)$.

Strikingly, reports based on clinical data and on in vivo animal models have suggested that antibody treatments leading to cell lysis and depletion could also induce a long-term anti-tumor response through the triggering of an adaptive memory response, a phenomenon that has been termed the "vaccinal" effect of antibody treatment (7-21). Anti-CA125- (8), anti-MUC1- (9), anti-HER2/neu- $(10,11)$, and anti-EGFR (12)-specific B and $\mathrm{T}$ cell responses have been reported in cancer patients following $\mathrm{mAb}$ therapy. Studies in murine models reported also that the therapeutic effect of anti-CD20 (13-16), anti-HER2/neu (17-20), or anti-EGFR (21) mAbs depends on the induction of an adaptive immune response and on the presence of T cells. The anti-HER2/ neu studies revealed an antibody-mediated mechanism in which danger signals activate both innate and T cell-mediated immune responses (17-20). In addition, these studies showed that an immunological memory is required for tumor control and to enable animals to resist a tumor rechallenge (13-21). The idea that antibody treatment can lead to a long-lasting adaptive immune response in patients has therefore opened an exciting avenue for the manipulation of the host immune surveillance. Interestingly, chemotherapy that is often used in combination with therapeutic anti-tumor antibodies can also, in some circumstances, induce an immune adaptive response. A number of studies have launched the concept of immunogenic cell death (ICD) induced by chemotherapeutic drugs $(22,23)$ and have suggested that these drugs can induce an adaptive immune response against tumor cells. The molecular mechanisms of ICD induction involves the exposition of calreticulin (CRT) on the surface of the dying tumor cells, the release of danger signals such as the high-mobility group box 1 protein (HMGB-1) and ATP, leading to the processing of tumor antigens by stimulated dendritic cells (DCs) and to Tc1 polarization of CD8 ${ }^{+}$T lymphocytes (24).

However, a number of anti-tumor antibodies target molecules expressed by tumor cells belonging to the hematopoietic lineage and, hence, also target their normal cell counterparts, notably lymphocytes (anti-CD20,-CD52,-CD38, SLAMF7, etc.) and myeloid cells (anti-CD30,-CD33, etc.). These antibodies are mostly depleting antibodies and one can think, therefore, that it may impact the effects of $m A b$ therapy on the long-term immune response of the patients. In patients with inflammatory/autoimmune diseases and in cancer patients, the iterative infusion of anti-lymphocyte depleting mAbs leads to a profound, selective, and, sometimes, long-lasting depletion of $\mathrm{B}$ and/or $\mathrm{T}$ cells. Quantitative and qualitative changes in $\mathrm{B}$ and $\mathrm{T}$ cell subsets and repertoires have been reported following reconstitution (25-33). Some patients with rheumatoid arthritis (RA) remain lymphopenic 12 years after alemtuzumab (anti-CD52) treatment, and the analysis of their peripheral $\mathrm{T}$ cell compartments shows that naïve and central memory $\mathrm{T}$ cell $\left(\mathrm{T}_{\mathrm{CM}}\right)$ numbers are reduced, while that of effector memory $\mathrm{T}$ cells $\left(\mathrm{T}_{\mathrm{EM}}\right)$ is similar to that of RA patients not treated with alemtuzumab (32). There is also an extensive literature concerning abnormalities of $\mathrm{B}$ cell repopulation after rituximab (anti-CD20) treatment, including a delayed recovery of circulating $\mathrm{CD} 27^{+}$memory B cells and/or changes in immunoglobulin repertoires, in patients with autoimmune diseases (RA, systemic lupus erythematosus, and active primary Sjögren's syndrome) or with B cell non-Hodgkin lymphoma (B cell NHL) (25-31, 33). Moreover, B cell depletion after rituximab treatment in autoimmune disorders affects $\mathrm{T}$ cell differentiation and activation and provokes an increase in regulatory $\mathrm{T}$ cell (Treg) numbers (34-38).

Together, these different studies indicate that the consequence of antibody treatment on the host adaptive immunity is multifaceted. Some therapeutic mAbs, particularly mAbs directed against immune cells, could not only have overall longterm unwanted effects on T cell compartments but also favor the emergence of specific anti-tumor adaptive immune responses.

\section{ANTIBODY TREATMENTS CAN INDUCE SPECIFIC MEMORY CELLULAR RESPONSES}

Studies have demonstrated that, although the clearance of $\mathrm{CD} 20^{+}$ lymphoma cells or of $\mathrm{HER}^{+}$or $\mathrm{EGFR}^{+}$carcinoma cells by antiCD20 (13), anti-HER2/neu (17), or anti-EGFR (21) antibodies, respectively, requires innate immunity, a phase of tumor growth control involving antigen-specific $\mathrm{T}$ cell response is then established (13-21).

With regard to anti-CD20 therapy, this phenomenon was initially shown in our laboratory using an experimental setting where mouse lymphoma $\mathrm{T}$ cells expressing human $\mathrm{CD} 20$ (huCD20) molecules (EL4-huCD20) injected intravenously (i.v.) into $\mathrm{C} 57 \mathrm{Bl} / 6$ mice were targeted with an anti-huCD20 antibody (13-15). In this preclinical model, the depletion of $\mathrm{CD} 4^{+} \mathrm{T}$ cells, both at the initiation of the treatment and upon tumor rechallenge 
in surviving mice, dramatically reduced the protective effect of the antibody (13). Interestingly, a lack of $\mathrm{CD}^{+} \mathrm{T}$ cells at the beginning of the treatment did not impair its efficacy. By contrast, these latter cells were required when animals were rechallenged with tumor cells (13). This long-term protective effect based on $\mathrm{T}$ cell immunity, specifically directed against $\mathrm{CD} 20^{+}$and not $\mathrm{CD} 20^{-}$tumor cells, could be reinforced by IL-2 treatment at the time of rechallenge (13). Importantly, the anti-CD20 treatment modified the phenotype of $\mathrm{CD} 4^{+} \mathrm{T}$ cells by preventing the expansion of pro-tumor $\mathrm{CD} 4^{+}$Treg cells and by inducing a polarization toward a Th1 phenotype through the IFN $\gamma / \mathrm{IL}-12$ axis. This was associated with an expansion of a pool of memory $\mathrm{CD} 4^{+} \mathrm{T}$ cells in long-term surviving mice (14) as well as by a change in the $\mathrm{CD}^{+} / \mathrm{CD}^{+} \mathrm{T}$ cell ratio. The vaccinal effect of this anti-CD20 therapy was also shown to be dependent on the presence of the Fc region of the antibody (13), and on the activation of myeloid DC producing IL-12 (14). It was further demonstrated by others, using transgenic mice that this vaccinal effect relies on the binding of anti-CD20 antibody to human FcyRIIa and FcyRIIIa (15). Thus, the use of a depleting $\mathrm{mAb}$ targeting an antigen such as CD20 enables the triggering of a cascade of events that leads to the setting of a long-term adaptive immunity against this molecule. A recent study explored the relative role of $\mathrm{CD} 4^{+}$and $\mathrm{CD} 8^{+} \mathrm{T}$ cells in the host adaptive immune response triggered by an anti-CD20 mAb. A model of immune-competent mice bearing syngeneic mouse B cell lymphoma (A20) and treated with a mouse anti-mouse CD20 mAb was set up (16). The authors observed in this model that $\mathrm{CD} 8^{+} \mathrm{T}$ cells, instead of $\mathrm{CD} 4^{+} \mathrm{T}$ cells as described in the EL4-huCD20 model, played an essential role in CD20 mAb-mediated tumor regression. Anti-CD20 mAb induced type I IFN production by macrophages that promoted DC-mediated cross-presentation and priming of tumor-specific CTL (16). Interestingly, anti-CD20 mAb treatment resistance and tumor relapse in this model were associated with a much higher percentage of CTLA- 4 expressing Treg. Finally, CTLA- 4 blockade could synergize with anti-CD20 treatment to overcome the resistance to the development of an adaptive immune response in this preclinical model (16).

The differences in the results about $\mathrm{T}$ cell compartments involved in the mAb-induced long-term protective effect observed between the latter study and the previous one might be related to the differences in the nature of tumor cells injected (syngeneic vs xenogeneic) and the injection route (subcutaneously $v s$ i.v.). Although highlighting the potential vaccinal effect of therapeutic mAbs, mice models based on the inoculation with EL4-huCD20 tumor cells (13-15) present some limitations: (i) the huCD20 molecule is a xenoprotein which likely displays a weak immunogenicity, reinforcing the $\mathrm{mAb}$-induced anti-tumor specific $\mathrm{T}$ cell responses in mice; (ii) the anti-huCD20 mAb used in the studies on the vaccinal effect (13-15) does not exhibit any cross-reactivity with mouse CD20 and, hence, does not deplete non-malignant mouse $\mathrm{B}$ cells, contrary to mouse syngeneic models where mouse anti-mouse CD20 are used or to rituximab treatment in FL patients. Of note, in the different studies described above, anti-CD20 mAbs are used as a single agent. This does not reflect anti-CD20 treatment usually indicated for initiation therapy in NHL patients, performed in combination with chemotherapy (cyclophosphamide, doxorubicin, vincristine, prednisone) (CHOP). It suggests that further studies in patients with cancer or autoimmune/inflammatory diseases and treated with rituximab only or in combination with other drugs could be of major interest to decipher the long-term impact of anti-CD20 mAbs on B and T cell compartments and on the emergence of specific anti-CD20 T cell responses. Some data suggest that anti-CD20 therapy is capable of reinforcing the priming of tumor-specific T cells in patients. First, in vitro experiments have shown that bone marrow-derived macrophages present an increased cross-priming function when cocultured with human B cell lymphoma cells in the presence of rituximab (16). Second, anti-idiotype $\mathrm{T}$ cell responses have been detected in some FL patients following rituximab therapy (39).

Several preclinical studies have shown the important role of the host adaptive immune system in the anti-HER2/neu mAbmediated anti-tumor immunity using HER2/neu ${ }^{+}$mouse tumor models (17-20). Park and his collaborators demonstrated that the anti-tumor activity of an anti-HER2/neu antibody is abrogated into Rag- $1^{-/}$mammary tumor-bearing mice (17). Of note, the same anti-HER2/neu antibody treatment in immune-competent mice induced tumor-specific $\mathrm{CD} 8^{+} \mathrm{T}$ cells producing IFN- $\gamma$ and a protective memory $\mathrm{T}$ cell response that could be evidenced when mAb-treated surviving animals were rechallenged with tumor cells (17). It has also been demonstrated in another preclinical investigation that $\mathrm{CD} 8^{+} \mathrm{T}$ cell depletion in HER2/neu ${ }^{+}$tumorbearing mice treated with a combination of antibodies directed against HER2/neu and death receptor 5 abrogates the anti-tumor protective effect (19). A recent study using mouse models of HER2/neu ${ }^{+}$breast cancer and examining tumor samples from HER2/neu ${ }^{+}$breast cancer patients revealed that IL-21 expression in tumor-infiltrating $\mathrm{CD} 4^{+} \mathrm{T}$ cells is enhanced following antiHER2/neu mAb therapy and that IL21R expression on CD8 ${ }^{+}$ $\mathrm{T}$ cells is required for optimal mAb efficacy (40). Mortenson et al. have also evaluated the role of $\mathrm{CD} 4^{+} \mathrm{T}$ cells using mice engrafted with tumor cells overexpressing HER2/neu and treated with an anti-HER2/neu antibody in conjunction with CD4 depletion or CD40L blockade. They have shown that, in addition to $\mathrm{CD} 8^{+} \mathrm{T}$ cells, $\mathrm{CD} 4^{+} \mathrm{T}$ cells are also essential for anti-HER2/ neu antibody-mediated tumor regression. The role of $\mathrm{CD} 4^{+}$in this model was not limited to $\mathrm{CD} 8^{+} \mathrm{T}$ cells help, but was also dependent on the production of IFN $\gamma$ by innate cells, leading to MHC II expression on the tumor cells used in the model, allowing direct recognition of these cells by $\mathrm{CD}^{+} \mathrm{T}$ cells (18). This result suggested that $\mathrm{mAb}$ treatment can favor a direct recognition by specific $\mathrm{CD} 4^{+} \mathrm{T}$ cells of tumor-associated antigens (TAAs) in complex with MHC II molecules at the surface of tumor cells. However, this observation is strongly tempered by the fact that, unlike MHC I molecules that are ubiquitously expressed in human nucleated cells, the expression of MHC II molecules on solid tumors is far more restricted. MHC II expression has been detected on a variety of human cancer types (including ovarian, colorectal and lung cancer, melanoma, and breast carcinomas) (41), but is highly dependent on the immunological environment and can be modulated by cytokines (41). Furthermore, the capacity of MHC $\mathrm{II}^{+}$tumor cells to prime naive $\mathrm{CD} 4^{+} \mathrm{T}$ cells is dependent on their ability to process tumor-derived antigens (41, 
42). In patients, several clinical studies have demonstrated the induction of specific anti-TAA $\mathrm{T}$ and $\mathrm{B}$ cell responses following $\mathrm{mAb}$ treatment (8-12). An induction of CA125-specific B and $\mathrm{T}$ cell responses after injection of a murine anti-CA125 mAb (used as an immunoscintigraphic agent in patients with ovarian cancer) has been observed and correlated with improved survival (8). Moreover, an increase in MUC1-specific T cells frequency has been observed in cancer patients treated with anti-MUC1 mAb (9). The analysis of metastatic breast cancer patient immunity before and after trastuzumab (anti-HER2/neu) therapy showed that the percentage of patients exhibiting specific anti-HER2/ neu $\mathrm{B}$ and $\mathrm{T}$ cell responses was increased, and the frequencies of memory specific cells were higher following mAb treatment (10). Patients with head and neck cancer (HNC) who have been treated with cetuximab (anti-EGFR) also presented a dramatic increase in tumor-specific CTL cells, their activation being dependent on NK-DCs cross-talk (12).

Finally, one can argue that the vaccinal effect of therapeutic antibodies is induced in many different immune contextures, including infectious diseases (Table 1). It was shown that the treatment of FrCas(E) retrovirus-infected mice with a neutralizing $\mathrm{mAb}$ resulted in a strong long-lasting immunity (43). The authors demonstrated that the mAb therapy inhibited an expansion of immunosuppressive Treg, reinforcing antiviral $\mathrm{CD} 8^{+} \mathrm{T}$ cell responses (44). Likewise, a study examining efficacy of mAbs against the gag envelop protein of HIV showed that monkeys receiving the anti-gag treatment exhibited higher gagspecific T cell responses (45).

\section{VACCINAL EFFECT: HOW DOES IT WORK?}

Until recently, mAb therapy was viewed as a passive therapy acting rapidly and directly against tumor cells and was not classified as "biotherapy." CDC and ADCC/ADCP exerted by cells from the innate immunity through the engagement of $\mathrm{Fc} \gamma \mathrm{R}$ are considered to play an important role in the in vivo efficacy of anti-tumor antibodies both in preclinical tumor models and in treated cancer patients (47). The significant correlations of FcyR polymorphisms with the clinical outcome in patients treated with rituximab (48, $49)$, trastuzumab $(50,51)$, and cetuximab $(52,53)$ argue in favor of a role of $\mathrm{Fc} \gamma \mathrm{R}^{+}$immune cells activation in the clinical responses to $\mathrm{mAb}$-based treatment. However, as other studies revealed no such associations in patients with breast cancer (54) and in follicular lymphoma $(55,56)$, it raises the possibility of additional immune mechanisms to account for the clinical benefit of $\mathrm{mAb}$ based immunotherapy. Notably, the duration and strength of clinical responses following $\mathrm{mAb}$ treatment may be linked to the ability of tumor antigen-specific $\mathrm{mAb}$ to elicit an adaptive cellular immunity.

Various hypotheses may explain the induction of an adaptive immunity following antibody-mediated effector functions (Figure 1). A role for DCs present at the tumor site is supported by their ability to internalize immune complexes via activating $\mathrm{Fc} \gamma \mathrm{R}$ and to promote efficient MHC II- and MHC I-restricted presentation of peptides from exogenous IgG-complexed antigens (57-59). It has been reported that anti-CD20 antibody-treated lymphoma cells are taken up and processed by DCs with subsequent cross-presentation of tumor-derived antigens to T cells (60). In a human glioma model, Fc $\gamma$ R-dependent engulfment of cetuximab-coated glial tumor cells by DCs leads to an increased number of anti-tumor $\mathrm{CD}^{+} \mathrm{T}$ cells (61). Interestingly, DC cross-presentation of MHC I-restricted tumor peptides derived from exogenous immune complexes could be improved using blocking antibody directed against inhibitory Fc $\gamma$ RIIb $(58,61)$. Moreover, the crucial role of Fc $\gamma$ R-expressing DC has also been recently demonstrated when comparing a bispecific anti- $\mathrm{G}_{\mathrm{D} 2} \mathrm{x}$ anti$\mathrm{G}_{\mathrm{D} 3}$ antibody (BsAb) lacking the immunoglobulin $\mathrm{FC}$ region $v s$ the same trifunctional BsAb comprising an appropriate $\mathrm{Fc}$

TABLE 1 | Effects of monoclonal antibody (mAb) treatment on host adaptive immunity.

\begin{tabular}{|c|c|c|c|c|}
\hline mAb target & mAb & Preclinical model/disease & Effects on adaptive immunity & Reference \\
\hline MUC1 & $\begin{array}{l}\text { BrevaRax } \\
\text { (AR20.5) }\end{array}$ & MUC1+ tumors in cancer patients & Induces specific anti-MUC1 B and T cell responses & (9) \\
\hline CA125 & B43.13 & Ovarian cancer patients & Induces specific anti-CA125 B and T cell responses & (8) \\
\hline CD20 & $\begin{array}{l}\text { Mouse } \\
\text { anti-mouse } \\
\text { CD20 }\end{array}$ & Syngeneic B cell lymphoma (mouse model) & Induces long-term protective T cell immunity & (16) \\
\hline HER2/neu & $\begin{array}{l}7.16 .4 / \\
\text { Trastuzumab }\end{array}$ & $\begin{array}{l}\mathrm{HER} 2 / \mathrm{neu}^{+} \text {tumor (mouse model) and biopsies } \\
\text { from breast cancer patients }\end{array}$ & Induces anti-tumor memory $T$ cell responses & $(17-20,40)$ \\
\hline
\end{tabular}




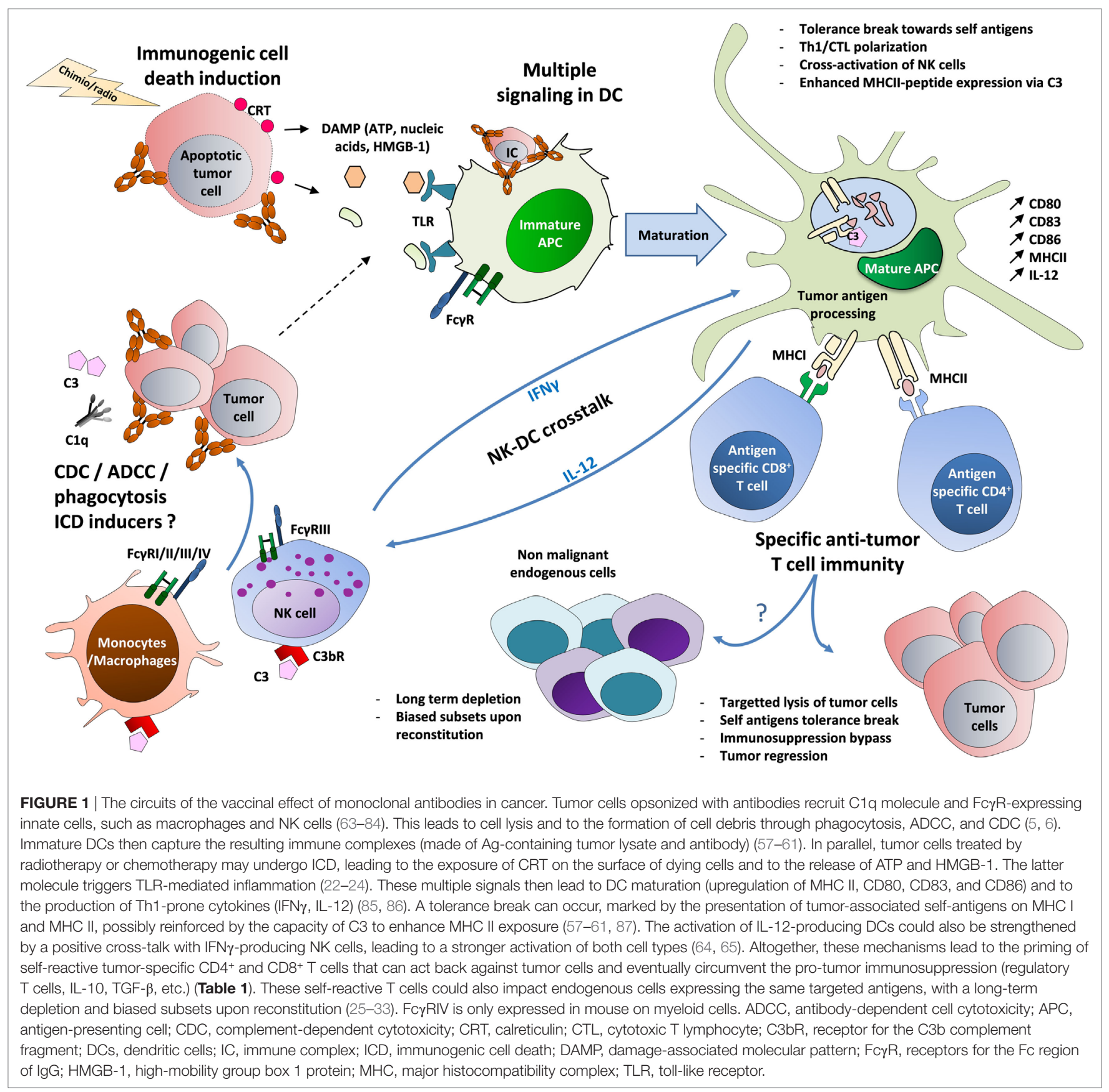

region. Only the trifunctional antibody elicited a polyvalent, DC-dependent long lasting anti-tumor T cell response (62).

Several studies demonstrated that, upon mAb therapy, a cross-talk between NK cells and DC can occur $(12,63,64)$. One of the most illustrative studies showed that cetuximab-activated $\mathrm{NK}$ cells could induce an IFN $\gamma$-dependent expression of DC maturation markers, of antigen processing machinery components such as TAP-1/2 and Th1-related cytokines, resulting in enhanced cross-presentation to CTL specific for EGFR-derived peptides (12). MAb-mediated NK-DC cross-talk may also favor antigen spreading by promoting DC maturation, tumor cells destruction, and $\mathrm{CD}^{+} \mathrm{T}$ cells priming. Moreover, in the same study, mature DCs stimulated mAb-activated NK cells in return, leading to an increased secretion of IFN $\gamma$ (12). In a mouse model of C57Bl/6 mice injected i.v. with huCD20 $0^{+}$tumor cells and treated with an anti-huCD20 antibody, we have shown that IFN $\gamma$-producing NK cells, costimulatory molecules-expressing mature DC, and IL-12 production are critical for $\mathrm{mAb}$-induced vaccinal effect (14). Recently, a study using the same model of anti-huCD20 $\mathrm{mAb}$ treatment of tumors in transgenic mice expressing human $\mathrm{Fc} \gamma \mathrm{R}$ has demonstrated that the induction of anti-tumor adaptive immunity is dependent on the expression of Fc $\gamma$ RIIA on DC and 
on FcyRIIIA-mediated ADCC (15). A recent study using a syngeneic model of $\mathrm{B}$ cell lymphoma in mice has shown that depletion of DC impairs the anti-tumor effect of anti-CD20 mAb (16). In this model, $\mathrm{mAb}$ treatment increased the cross-presentation of $\mathrm{DC}$ and the cross-priming of anti-tumor $\mathrm{CD} 8^{+} \mathrm{T}$ cells involved in tumor regression (16). Moreover, IL-12 and IFN $\gamma$ production by NK cells enhanced the anti-tumor efficacy of trastuzumab in a model of murine colon adenocarcinoma (65).

The relationship between macrophages and tumors is complex as some of them exhibit anti-tumor activity (M1 macrophages) and others, termed M2 macrophages, secrete tumor growth factors and favor angiogenesis. In a clinical trial, the addition of cetuximab to bevacizumab (a humanized anti-VEGF-A mAb) plus chemotherapy resulted in a decreased progression-free survival in metastatic colorectal cancer. The authors could then show that M2 macrophages were the dominant $\mathrm{Fc} \gamma \mathrm{RIII}^{+}$population in the tumor microenvironment of these patients (66). However, macrophages are likely crucial to the efficacy of therapeutic antibodies thanks to their expression of different types of Fc $\gamma \mathrm{R}$, enabling ADCP. There are several in vitro and in vivo evidence supporting macrophages as effectors of therapeutic antibodies in cancer. In vitro macrophage phagocytosis of tumor cells in response to anti-CD20 and anti-HER2/neu mAbs has been demonstrated in a number of studies using human macrophages (67-71). Interestingly, all human IgG subclasses, including isotypes which exhibit a low NK cell-mediated ADCC due to their poor binding to FcyRIIIa, have the potential to engage other


stimulate macrophage-dependent phagocytosis (72). It has also been demonstrated that macrophage-mediated phagocytosis contributes to the therapeutic activity of anti-CD38 antibody in multiple myeloma and potentially other hematological tumors (73). In vivo studies using anti-CD20 mAbs have also demonstrated a crucial role of monocytes and macrophages as effectors of anti-tumor activity of antibodies, while depletion or defects in these populations induce impaired responses to $\mathrm{mAb}$ treatment $(74,75)$. Some studies have also shown that Kupffer cells in the liver immobilize and eliminate circulating tumor cells by engulfment of opsonized cells, thus probably contributing to the prevention of metastasis (75-77). Several clinical investigations have found that a high number of macrophages within tumors correlate with poor prognosis in many different types of cancers (78). However, the impact on prognosis of macrophage infiltration is dependent on the tumor microenvironment and on the combination of therapeutics as shown in different studies in lymphoma patients (79, 80). High tumor-associated macrophages number was associated with an adverse outcome in chemotherapy-treated patients, while it was associated with longer survival rates when chemotherapy was combined with rituximab (79). This study further implicates macrophages as important effectors for the therapeutic benefit of antibody treatment in patients and suggests that the balance between macrophages and mature DCs may provide some clues in the differential priming of the $\mathrm{T}$ cell response after antibody therapy. Interestingly, it has been reported that human macrophages and DCs for therapeutic use equally present TAA to $\mathrm{CD}^{+} \mathrm{T}$ cells after phagocytosis of $\gamma$-irradiated melanoma cells, indicating that macrophages can contribute to the recruitment of T cells as efficiently as DCs (81). Thus, one can hypothesize that phagocytosis of IC by Fc $\gamma \mathrm{R}^{+}$macrophages can lead to an efficient CD8 ${ }^{+} \mathrm{T}$ cell cross-presentation. Of note, a role of type I IFN-producing macrophages in promoting cross-presentation of B cell lymphoma antigens by DCs has been recently reported (16).

Finally, the recruitment of complement molecules has also been reported after antibody infusions. The binding of $\mathrm{C} 1 \mathrm{q}$ to the $\mathrm{Fc}$ region of $\mathrm{mAbs}$ can induce the lysis of target cells and promotes the recruitment of complement receptor-expressing effector cells $(82,83)$. These mechanisms are central in the anti-tumor activity of some therapeutic antibodies, such as ofatumumab, an anti-CD20 $\mathrm{mAb}$ that has been optimized for its capacity to bind $\mathrm{Clq}$ and to induce CDC (84). Interestingly, recent studies suggest that the $\mathrm{C} 3$ complement molecule has a role in the $\mathrm{T}$ cell response to apoptotic cell-associated antigens. The authors of the study showed that C3 acts as a chaperone protein in the intracellular processing of antigens derived from apoptotic cells and can, therefore, modulate $\mathrm{T}$ cell responses to self-antigens displayed on dying cells (87). This study underlines a new link between complement molecules recruited by immune complexes and the ability to promote presentation of tumor-derived antigens from dying cells to T cells.

\section{ANTIBODY-INDUCED EXPANSION OF AUTOREACTIVE T CELLS? TO BE OR NOT TO BE IMMUNOGENIC...}

Thus, all these data strongly support the hypothesis that the induction of a $\mathrm{T}$ cell response against $\mathrm{mAb}$-targeted cells plays a key role in the long-term efficacy of mAb-based therapies, raising important questions about the specificity and the evolution of these responses all along the treatment. Furthermore, it is still unclear whether the induction of a long-term adaptive response that follows $\mathrm{mAb}$ treatment is related to the tumor nature of the target cells or whether it also applies to non-malignant cells depleted upon $\mathrm{mAb}$ treatment. Finally, since there are different forms of $\mathrm{mAb}$-induced killing of target cells, it is unclear whether differences arise between normal and tumor cells in terms of immunogenicity once killed.

Most tumor antigens are self-antigens that elicit weak $\mathrm{T}$ cell responses if any as a consequence of immune tolerance. However, anti-tumor $\mathrm{mAb}$ treatment may at least transiently break tolerance to self-antigens expressed on tumor cells (17, 88). In cancer patients, treatment with trastuzumab and chemotherapy increases the frequency of $\mathrm{CD} 4^{+} \mathrm{T}$ specific for HER2/neu peptides already known to bind multiple HLA-DR molecules. Some of these peptides have recently been identified as epitopes exhibiting a high affinity to a variety of HLA class II molecules $(10,89,90)$. Likewise, T cell responses to MUC1 were observed following anti-MUC1 $\mathrm{mAb}$ treatment using ELISPOT assays in response to stimulation with wild-type 31 mer MUC1 peptide (9). Furthermore, the staining of $\mathrm{CD}^{+}{ }^{+} \mathrm{CD} 8^{+} \mathrm{T}$ cells with a tetramer showed a higher frequency of $\mathrm{EGFR}_{853-861}$-specific $\mathrm{T}$ cells in HNC patients treated with cetuximab alone or in combination with chemotherapy than in cetuximab-naïve patients. It suggests that 
wild-type EGFR expressed on HNC cells could induce a specific immune response in vivo (12).

These results suggest that therapeutic mAbs treatment can lead to the expansion of preexisting $\mathrm{T}$ cells specific for non-mutated self-antigens. An emerging concept is that thymic deletion prunes but does not eliminate self-specific $\mathrm{CD} 4^{+}$and $\mathrm{CD} 8^{+} \mathrm{T}$ cells and that some self-peptide/MHC-restricted T cells can be detected in frequencies similar to those of the $\mathrm{T}$ cells specific for non-self antigens (91-96).

Interestingly, several studies of HLA ligandome or selfimmunopeptidome have identified $\mathrm{CD}^{+}$and $\mathrm{CD}^{+} \mathrm{T}$ cell epitopes derived from $\mathrm{B}$ cell differentiation antigens (in particular, from CD19 and CD20 antigens) that could generate autoreactive cytotoxic $\mathrm{T}$ cell responses to $\mathrm{B}$ cell leukemia and lymphoma in patients with B cell malignancies (97-100). In one study, the authors analyzed the natural ligandome in primary chronic lymphocytic leukemia (CLL) patients by immunoaffinity purification of HLA-I and HLA-II molecules from PBMC followed by liquid chromatography/mass spectrometry analysis of HLA ligands. This analysis allowed the identification of non-mutated tumor-associated $\mathrm{T}$ cell self-antigens exclusively and frequently found in the HLA ligandome of CLL cells, by comparison with the HLA ligand proteomes of healthy donors. Furthermore, they evidenced an immune recognition by $\mathrm{T}$ cells of these self-antigens in CLL patients (99). Moreover, a recent report has demonstrated the role of $\mathrm{T}$ cells bearing low-avidity TCR for self-antigens in the immune surveillance of spontaneous lymphoma B cells that express $\mathrm{MHC}$ molecules presenting self-peptides in conjunction with high levels of costimulatory molecules and Fas (101). In line with these observations, T cells directed against tumor $B$ cells could be expanded from tumor and peripheral blood of patients with B cell NHL (102). In hematological diseases, endogenous preexisting $\mathrm{T}$ cell response directed against tumor-specific clonal immunoglobulin expressed by lymphoma B cells [idiotype (Id)] has been used as a target for active immunotherapy (103). In addition, it has been shown that peptides derived from B-cell receptor pathway components are presented in the context of MHC I and MHC II molecules in patients with lymphoma (104). The CD20 molecule itself could give rise to self-peptides targeted by T cells. A strategy to detect and expand allo-MHC-restricted T cells reactive to self-tumor antigens resulted in the detection of 37 non-mutated epitopes from CD20 and myeloperoxydase (100).

Of note, a large majority of cancer patients are treated with tumor-targeting mAbs in combination with chemotherapy or radiotherapy. Thus, one can think that the capacity of mAb treatment to induce adaptive immune responses against selfantigens could be related to inflammatory signals provided by chemotherapy or radiotherapy-induced ICD. The molecular mechanisms of ICD implicate the exposure of CRT on the cell surface, the secretion of ATP, and the release of the non-histone chromatin-binding protein HMGB-1. The emission of these damage-associated molecular patterns (DAMPs) is associated with the secretion of immunostimulatory cytokines such as type I IFN. Such DAMPs are then able to recruit antigen-presenting cells, including DCs, to the site of ICD and promote dead cellassociated antigens presentation to $\mathrm{CD}^{+}$and $\mathrm{CD}^{+} \mathrm{T}$ cells resulting in the priming of a robust cellular response (85). Several drugs, including various chemotherapeutics commonly used in the clinic (doxorubicin, mitoxantrone, bleomycin, bortezomib, cyclophosphamide, oxaliplatin, etc.), have the ability to provoke ICD (86). However, there is growing evidence that some therapeutic mAbs, as single agents, could also be ICD inducers. In a mouse model of mammary tumors where animals were treated with an anti-HER2/neu antibody, the release of HMGB-1 was essential for antibody-mediated tumor regression. Based on the results obtained in $\mathrm{Myd} 88^{-/-}$mice, the authors suggested that anti-HER2/neu antibody could induce HMGB-1 release in the tumor microenvironment, which enhanced innate responses via the MyD88 pathway and promoted the priming of adaptive immune cells, leading to an increased tumor clearance (17). Moreover, 7A7, an anti-murine EGFR mAb, could elicit strong tumor-specific CTL responses in hosts by inducing ICD of tumor cells in an Fc-independent manner (105). Interestingly, a recent study has shown that programmed-cell death induced by the type II anti-CD20 antibody obinutuzumab (GA-101) is associated with the release of significant levels of DAMP that could enhance DC maturation and subsequent T cell activation (106). Moreover, a recent study reported that both obinutuzumab and rituximab induced HMGB-1 release from diffuse large B-cell lymphoma (DLBCL) cells after a 4-h treatment (107). The same study showed that treatment with rituximab plus cyclophosphamide, doxorubicin, vincristine, and prednisone, but not $\mathrm{CHOP}$ alone, significantly increased plasma HMGB-1 and decreased IL-10 concentrations in DLBCL patients. Furthermore, the conditioned medium from rituximab-treated DLBCL cells could induce DC maturation and increased their capacity to activate T cell responses (107). In line with these observations, long-term complete remissions have been reported after single-agent rituximab treatment in different clinical trials in patients with follicular lymphoma $(108,109)$.

\section{CONCLUDING REMARKS}

Therapeutic mAbs used in oncology, inflammatory, and/or autoimmune disorders can exert depleting activity against target cells by inducing direct apoptosis and/or by recruiting effector cells from the innate immunity. Besides delayed recovery of target cells and impaired reconstitution of depleted populations in terms of frequencies and phenotype, lymphocytes depleting$\mathrm{mAb}$ treatment could also have dramatic consequences in the network of cells from the adaptive immune compartment. As expected, the depletion of one particular immune population could have bystander effects on the homeostasis and the functions of other non-targeted immune compartments. This effect has been extensively described in autoimmune disorders treated with rituximab, where $\mathrm{B}$ cell depletion induces dramatic changes in T cell compartments.

Moreover, as depleting mAbs are potentially ICD inducers, it is likely that an adaptive immune response against target cells could be mounted following mAb treatment. Different preclinical studies (mostly in models with tumor-bearing mice treated with anti-tumor mAbs), strengthened by a few observations in human clinical studies, have shown that therapeutic antibodies 
have a vaccinal effect likely responsible for the long-lasting clinical responses that have been observed. These long-lasting anti-tumor effects are mediated by $\mathrm{CD} 4^{+}$and $\mathrm{CD} 8^{+} \mathrm{T}$ cells. The role of Fc $\gamma$ Rs in the induction of this adaptive immune response following $\mathrm{mAb}$ therapy supports further studies to carefully examine the impact of the structural properties of therapeutic $\mathrm{mAbs}$ on their ability to elicit strong adaptive immune responses. In particular, it is now well established that Fc sequences as well as the nature of $\mathrm{Fc}-\mathrm{CH} 2$ domain-N-linked oligosaccharide have an impact on IgG/Fc $\gamma \mathrm{R}$ interactions and, thus, could influence the vaccine effect of mAbs. Interestingly, Fc domain variants of antiHIV-1 broadly neutralizing antibodies that exhibited enhanced binding capacity for activating human Fc $\gamma \mathrm{R}$, such as Fc $\gamma$ RIIa and FcyRIIIa, also presented an augmented in vivo protective activity in a model of HIV-infected humanized mice compared to wildtype or Fc $\gamma \mathrm{R}$ null binding variants. In this study, Fc-optimized variants induced faster and sustained reduction in viral load, with a significantly higher proportion of infected mice demonstrating viremia suppression (110).

This novel paradigm of a vaccinal effect of therapeutic antitumor antibodies should lead us to reexamine how antibody efficacy could be reinforced by the use, possibly in combination, of molecules impacting the immune surveillance. Among them are antibodies antagonizing ICP molecules that play a key role in the inhibition of the anti-tumor immune responses (e.g., PD-1, CTLA-4, LAG-3, TIM3, etc.) or antibodies that target immunostimulatory molecules (e.g., OX40, GITR, CD137, etc.) $(111,112)$. Furthermore, it has been suggested that the use of radiolabeled antibodies in combination with maintenance rituximab therapy in lymphoma may lead to an increase in complete response, associated with an increased recruitment of T cell subsets (113).

Finally, there are currently a number of scattered data reported in the literature indicating that $\mathrm{mAb}$ treatment may

\section{REFERENCES}

1. Hanahan D, Weinberg RA. Hallmarks of cancer: the next generation. Cell (2011) 144(5):646-74. doi:10.1016/j.cell.2011.02.013

2. Galon J, Costes A, Sanchez-Cabo F, Kirilovsky A, Mlecnik B, LagorcePagès C, et al. Type, density, and location of immune cells within human colorectal tumors predict clinical outcome. Science (2006) 313(5795):1960-4. doi:10.1126/science.1129139

3. Dieu-Nosjean MC, Antoine M, Danel C, Heudes D, Wislez M, Poulot V, et al. Long-term survival for patients with non-small-cell lung cancer with intratumoral lymphoid structures. J Clin Oncol (2008) 26(27):4410-7. doi:10.1200/ JCO.2007.15.0284

4. Fridman WH, Pagès F, Sautès-Fridman C, Galon J. The immune contexture in human tumours: impact on clinical outcome. Nat Rev Cancer (2012) 12(4):298-306. doi:10.1038/nrc3245

5. Sibéril S, Dutertre CA, Fridman WH, Teillaud JL. FcgammaR: the key to optimize therapeutic antibodies? Crit Rev Oncol Hematol (2007) 62(1):26-33. doi:10.1016/j.critrevonc.2006.12.003

6. Abès R, Teillaud JL. Modulation of tumor immunity by therapeutic monoclonal antibodies. Cancer Metastasis Rev (2011) 30(1):111-24. doi:10.1007/ s10555-011-9282-3

7. Deligne C, Siberil S, Teillaud JL. The vaccinal effect of monoclonal antibodies in cancer therapy. In: Rees RC, editor. Tumour Immunology and Immunotherapy. Oxford: Oxford University Press (2014). p. 357-71.

8. Noujaim AA, Schultes BC, Baum RP, Madiyalakan R. Induction of CA125-specific $\mathrm{B}$ and $\mathrm{T}$ cell responses in patients injected with result in inflammatory cell death that could lead to a targeted adaptive response. The induction of an ICD could be one of the mechanisms by which antibodies activate a long-term adaptive immunity against tumor cells and possibly normal cells. The latter is an important issue as it is still unclear whether a long-term adaptive immunity can be achieved when non-malignant cells are targeted with depleting mAbs, a situation found during the treatment of autoimmune pathologies. Various factors, such as the intrinsic immunogenicity of cells, their activation status, and the nature of the cell death pathway that is engaged, are all critical to determine whether cell death is immunogenic or not. Thus, monitoring adaptive immune responses after therapeutic $\mathrm{mAb}$ treatments might provide a further insight into the vaccine effect of $\mathrm{mAb}$ treatment, its impact on endogenous cell reconstitution, and its role in tumor control or relapse in high- or low-responder patients with cancer.

\section{AUTHOR CONTRIBUTIONS}

CD, SS, and J-LT conceived and wrote the manuscript. NJ and BM critically reviewed the manuscript. All the authors fully agreed with the manuscript content.

\section{FUNDING}

BM was supported by a fellowship from Cancer Research for Personalized Medicine (CARPEM) association. CD was supported by a fellowship from La Ligue Nationale Contre le Cancer and funding from Paris Descartes University. SS was supported by a grant from Fondation ARC pour la recherche sur le cancer (Grant number, ARC PJA20131200475), and J-LT and SS by funding from INSERM, Pierre et Marie Curie University and Paris-Descartes University.

MAb-B43.13 - evidence for antibody-mediated antigen-processing and presentation of CA125 in vivo. Cancer Biother Radiopharm (2001) 16(3):187-203. doi:10.1089/10849780152389384

9. de Bono JS, Rha SY, Stephenson J, Schultes BC, Monroe P, Eckhardt GS, et al. Phase I trial of a murine antibody to MUC1 in patients with metastatic cancer: evidence for the activation of humoral and cellular antitumor immunity. Ann Oncol (2004) 15(12):1825-33. doi:10.1093/annonc/mdh472

10. Taylor C, Hershman D, Shah N, Suciu-Foca N, Petrylak DP, Taub R, et al. Augmented HER-2 specific immunity during treatment with trastuzumab and chemotherapy. Clin Cancer Res (2007) 13(17):5133-43. doi:10.1158/10780432.CCR-07-0507

11. Knutson KL, Clynes R, Shreeder B, Yeramian P, Kemp KP, Ballman K, et al. Improved survival of HER2+ breast cancer patients treated with trastuzumab and chemotherapy is associated with host antibody immunity against the HER2 intracellular domain. Cancer Res (2016) 76(13):3702-10. doi:10.1158/0008-5472.CAN-15-3091

12. Srivastava RM, Lee SC, Andrade Filho PA, Lord CA, Jie HB, Davidson HC, et al. Cetuximab-activated natural killer and dendritic cells collaborate to trigger tumor antigen-specific T-cell immunity in head and neck cancer patients. Clin Cancer Res (2013) 19(7):1858-72. doi:10.1158/1078-0432. CCR-12-2426

13. Abès R, Gélizé E, Fridman WH, Teillaud JL. Long-lasting antitumor protection by anti-CD20 antibody through cellular immune response. Blood (2010) 116(6):926-34. doi:10.1182/blood-2009-10-248609

14. Deligne C, Metidji A, Fridman WH, Teillaud JL. Anti-CD20 therapy induces a memory Th1 response through the IFN- $\gamma / \mathrm{IL}-12$ axis and prevents 
protumor regulatory T-cell expansion in mice. Leukemia (2015) 29(4): 947-57. doi:10.1038/leu.2014.275

15. DiLillo DJ, Ravetch JV. Differential Fc-receptor engagement drives an antitumor vaccinal effect. Cell (2015) 161(5):1035-45. doi:10.1016/j.cell.2015.04.016

16. Ren Z, Guo J, Liao J, Luan Y, Liu Z, Sun Z, et al. CTLA-4 limits anti-CD20-mediated tumor regression. Clin Cancer Res (2017) 23(1):193-203. doi:10.1158/1078-0432.CCR-16-0040

17. Park S, Jiang Z, Mortenson ED, Deng L, Radkevich-Brown O, Yang X, et al. The therapeutic effect of anti-HER2/neu antibody depends on both innate and adaptive immunity. Cancer Cell (2010) 18(2):160-70. doi:10.1016/j. ccr.2010.06.014

18. Mortenson ED, Park S, Jiang Z, Wang S, Fu YX. Effective anti-neu-initiated antitumor responses require the complex role of $\mathrm{CD} 4+\mathrm{T}$ cells. Clin Cancer Res (2013) 19(6):1476-86. doi:10.1158/1078-0432.CCR-12-2522

19. Stagg J, Sharkey J, Pommey S, Young R, Takeda K, Yagita H, et al. Antibodies targeted to TRAIL receptor- 2 and ErbB-2 synergize in vivo and induce an antitumor immune response. Proc Natl Acad Sci U S A (2008) 105(42):16254-9. doi:10.1073/pnas.0806849105

20. Stagg J, Loi S, Divisekera U, Ngiow SF, Duret H, Yagita H, et al. Anti-ErbB-2 $\mathrm{mAb}$ therapy requires type I and II interferons and synergizes with anti-PD-1 or anti-CD137 mAb therapy. Proc Natl Acad Sci U S A (2011) 108(17):7142-7. doi:10.1073/pnas.1016569108

21. Yang X, Zhang X, Mortenson ED, Radkevich-Brown O, Wang Y, Fu YX. Cetuximab-mediated tumor regression depends on innate and adaptive immune responses. Mol Ther (2013) 21(1):91-100. doi:10.1038/mt.2012.184

22. Zitvogel L, Apetoh L, Ghiringhelli F, André F, Tesniere A, Kroemer G. The anticancer immune response: indispensable for therapeutic success? J Clin Invest (2008) 118(6):1991-2001. doi:10.1172/JCI35180

23. Zitvogel L, Kepp O, Kroemer G. Immune parameters affecting the efficacy of chemotherapeutic regimens. Nat Rev Clin Oncol (2011) 8(3):151-60. doi:10.1038/nrclinonc.2010.223

24. Ghiringhelli F, Apetoh L, Tesniere A, Aymeric L, Ma Y, Ortiz C, et al. Activation of the NLRP3 inflammasome in dendritic cells induces IL-1beta-dependent adaptive immunity against tumors. Nat Med (2009) 15(10):1170-8. doi:10.1038/nm.2028

25. Anolik JH, Barnard J, Cappione A, Pugh-Bernard AE, Felgar RE, Looney RJ, et al. Rituximab improves peripheral B cell abnormalities in human systemic lupus erythematosus. Arthritis Rheum (2004) 50(11):3580-90. doi:10.1002/ art.20592

26. Leandro MJ, Cambridge G, Ehrenstein MR, Edwards JC. Reconstitution of peripheral blood $\mathrm{B}$ cells after depletion with rituximab in patients with rheumatoid arthritis. Arthritis Rheum (2006) 54(2):613-20. doi:10.1002/art.21617

27. Roll P, Palanichamy A, Kneitz C, Dorner T, Tony HP. Regeneration of $B$ cell subsets after transient B cell depletion using anti-CD20 antibodies in rheumatoid arthritis. Arthritis Rheum (2006) 54(8):2377-86. doi:10.1002/ art.22019

28. Anolik JH, Barnard J, Owen T, Zheng B, Kemshetti S, Looney RJ, et al. Delayed memory B cell recovery in peripheral blood and lymphoid tissue in systemic lupus erythematosus after B cell depletion therapy. Arthritis Rheum (2007) 56(9):3044-56. doi:10.1002/art.22810

29. Pers JO, Daridon C, Bendaoud B, Devauchelle V, Berthou C, Saraux A, et al. B-cell depletion and repopulation in autoimmune diseases. Clin Rev Allergy Immunol (2008) 34(1):50-5. doi:10.1007/s12016-007-8015-4

30. Muhammad K, Roll P, Einsele H, Dörner T, Tony HP. Delayed acquisition of somatic hypermutations in repopulated IGD+CD27+ memory B cell receptors after rituximab treatment. Arthritis Rheum (2009) 60(8):2284-93. doi:10.1002/art.24722

31. Abdulahad WH, Meijer JM, Kroese FG, Meiners PM, Vissink A, Spijkervet FK, et al. B cell reconstitution and $\mathrm{T}$ helper cell balance after rituximab treatment of active primary Sjögren's syndrome: a double-blind, placebo-controlled study. Arthritis Rheum (2011) 63(4):1116-23. doi:10.1002/art.30236

32. Anderson AE, Lorenzi AR, Pratt A, Wooldridge T, Diboll J, Hilkens CM, et al. Immunity 12 years after alemtuzumab in RA: $\mathrm{CD}^{+} \mathrm{B}$-cell depletion, thymus-dependent T-cell reconstitution and normal vaccine responses. Rheumatology (2012) 51(8):1397-406. doi:10.1093/rheumatology/kes038

33. Adlowitz DG, Barnard J, Biear JN, Cistrone C, Owen T, Wang W, et al. Expansion of activated peripheral blood memory B cells in rheumatoid arthritis, impact of B cell depletion therapy, and biomarkers of response. PLoS One (2015) 10(6):e0128269. doi:10.1371/journal.pone.0128269
34. Sfikakis PP, Souliotis VL, Fragiadaki KG, Moutsopoulos HM, Boletis JN, Theofilopoulos AN. Increased expression of the FoxP3 functional marker of regulatory $\mathrm{T}$ cells following $\mathrm{B}$ cell depletion with rituximab in patients with lupus nephritis. Clin Immunol (2007) 123(1):66-73. doi:10.1016/j. clim.2006.12.006

35. Kessel A, Rosner I, Toubi E. Rituximab: beyond simple B cell depletion. Clin Rev Allergy Immunol (2008) 34(1):74-9. doi:10.1007/s12016-008-8074-1

36. Lund FE, Randall TD. Effector and regulatory B cells: modulators of CD4+ T cell immunity. Nat Rev Immunol (2010) 10(4):236-47. doi:10.1038/nri2729

37. Stroopinsky D, Katz T, Rowe JM, Melamed D, Avivi I. Rituximab-induced direct inhibition of T-cell activation. Cancer Immunol Immunother (2012) 61(8):1233-41. doi:10.1007/s00262-011-1168-2

38. Zhao Y, Lutalo PM, Thomas JE, Sangle S, Choong LM, Tyler JR, et al. Circulating $\mathrm{T}$ follicular helper cell and regulatory $\mathrm{T}$ cell frequencies are influenced by B cell depletion in patients with granulomatosis with polyangiitis. Rheumatology (2014) 53(4):621-30. doi:10.1093/rheumatology/ket406

39. Hilchey SP, Hyrien O, Mosmann TR, Livingstone AM, Friedberg JW, Young F, et al. Rituximab immunotherapy results in the induction of a lymphoma idiotype-specific T-cell response in patients with follicular lymphoma: support for a "vaccinal effect" of rituximab. Blood (2009) 113(16):3809-12. doi:10.1182/blood-2008-10-185280

40. Mittal D, Caramia F, Michiels S, Joensuu H, Kellokumpu-Lehtinen PL, Sotiriou C, et al. Improved treatment of breast cancer with anti-HER2 therapy requires interleukin-21 signaling in CD8+ T cells. Cancer Res (2016) 76(2):264-74. doi:10.1158/0008-5472.CAN-15-1567

41. Thibodeau J, Bourgeois-Daigneault MC, Lapointe R. Targeting the MHC Class II antigen presentation pathway in cancer immunotherapy. Oncoimmunology (2012) 1(6):908-16. doi:10.4161/onci.21205

42. Accolla RS, Lombardo L, Abdallah R, Raval G, Forlani G, Tosi G. Boosting the MHC class II-restricted tumor antigen presentation to CD4+ T helper cells: a critical issue for triggering protective immunity and re-orienting the tumor microenvironment toward an anti-tumor state. Front Oncol (2014) 4:32. doi:10.3389/fonc. 2014.00032

43. Nasser R, Pelegrin M, Michaud HA, Plays M, Piechaczyk M, Gros L. Longlasting protective antiviral immunity induced by passive immunotherapies requires both neutralizing and effector functions of the administered monoclonal antibody. J Virol (2010) 84(19):10169-81. doi:10.1128/JVI.00568-10

44. Nasser R, Pelegrin M, Plays M, Gros L, Piechaczyk M. Control of regulatory $\mathrm{T}$ cells is necessary for vaccine-like effects of antiviral immunotherapy by monoclonal antibodies. Blood (2013) 121(7):1102-11. doi:10.1182/ blood-2012-06-432153

45. Barouch DH, Whitney JB, Moldt B, Klein F, Oliveira TY, Liu J, et al. Therapeutic efficacy of potent neutralizing HIV-1-specific monoclonal antibodies in SHIV-infected rhesus monkeys. Nature (2013) 503(7475):224-8. doi:10.1038/ nature 12744

46. Sala A, Gresser I, Chassoux D, Maury C, Santodonato L, Eid P, et al. Inhibition of friend leukemia cell visceral metastases by a new monoclonal antibody and role of the immune system of the host in its action. Cancer Res (1992) 52(10):2880-9.

47. Dahal LN, Roghanian A, Beers SA, Cragg MS. Fc $\gamma$ R requirements leading to successful immunotherapy. Immunol Rev (2015) 268(1):104-22. doi:10.1111/ imr. 12342

48. Cartron G, Dacheux L, Salles G, Solal-Celigny P, Bardos P, Colombat P, et al. Therapeutic activity of humanized anti-CD20 monoclonal antibody and polymorphism in IgG Fc receptor FcgammaRIIIa gene. Blood (2002) 99(3):754-8. doi:10.1182/blood.V99.3.754

49. Weng WK, Levy R. Two immunoglobulin G fragment $\mathrm{C}$ receptor polymorphisms independently predict response to rituximab in patients with follicular lymphoma. J Clin Oncol (2003) 21(21):3940-7. doi:10.1200/ JCO.2003.05.013

50. Musolino A, Naldi N, Bortesi B, Pezzuolo D, Capelletti M, Missale G, et al. Immunoglobulin $\mathrm{G}$ fragment $\mathrm{C}$ receptor polymorphisms and clinical efficacy of trastuzumab-based therapy in patients with HER-2/neu-positive metastatic breast cancer. J Clin Oncol (2008) 26(11):1789-96. doi:10.1200/ JCO.2007.14.8957

51. Tamura K, Shimizu C, Hojo T, Akashi-Tanaka S, Kinoshita T, Yonemori K, et al. Fc $\gamma$ R2A and $3 \mathrm{~A}$ polymorphisms predict clinical outcome of trastuzumab in both neoadjuvant and metastatic settings in patients with HER2-positive breast cancer. Ann Oncol (2011) 22(6):1302-7. doi:10.1093/annonc/mdq585 
52. Zhang W, Gordon M, Schultheis AM, Yang DY, Nagashima F, Azuma M, et al. FCGR2A and FCGR3A polymorphisms associated with clinical outcome of epidermal growth factor receptor expressing metastatic colorectal cancer patients treated with single-agent cetuximab. JClin Oncol (2007) 25(24):3712-8. doi:10.1200/JCO.2006.08.8021

53. Bibeau F, Lopez-Crapez E, Di Fiore F, Thezenas S, Ychou M, Blanchard F, et al. Impact of Fc\{gamma\}RIIa-Fc \{gamma\}RIIIa polymorphisms and KRAS mutations on the clinical outcome of patients with metastatic colorectal cancer treated with cetuximab plus irinotecan. J Clin Oncol (2009) 27(7):1122-9. doi:10.1200/JCO.2008.18.0463

54. Hurvitz SA, Betting DJ, Stern HM, Quinaux E, Stinson J, Seshagiri S, et al. Analysis of Fcy receptor IIIa and IIa polymorphisms: lack of correlation with outcome in trastuzumab-treated breast cancer patients. Clin Cancer Res (2012) 18(12):3478-86. doi:10.1158/1078-0432.CCR-11-2294

55. Carlotti E, Palumbo GA, Oldani E, Tibullo D, Salmoiraghi S, Rossi A, et al. FcgammaRIIIA and FcgammaRIIA polymorphisms do not predict clinical outcome of follicular non-Hodgkin's lymphoma patients treated with sequential CHOP and rituximab. Haematologica (2007) 92(8):1127-30. doi:10.3324/ haematol.11288

56. Kenkre VP, Hong F, Cerhan JR, Lewis M, Sullivan L, Williams ME, et al. $\mathrm{Fc}$ gamma receptor $3 \mathrm{~A}$ and $2 \mathrm{~A}$ polymorphisms do not predict response to rituximab in follicular lymphoma. Clin Cancer Res (2016) 22(4):821-6. doi:10.1158/1078-0432.CCR-15-1848

57. Regnault A, Lankar D, Lacabanne V, Rodriguez A, Théry C, Rescigno M, et al. Fcgamma receptor-mediated induction of dendritic cell maturation and major histocompatibility complex class I-restricted antigen presentation after immune complex internalization. J Exp Med (1999) 189(2):371-80. doi:10.1084/jem.189.2.371

58. Dhodapkar KM, Krasovsky J, Williamson B, Dhodapkar MV. Antitumor monoclonal antibodies enhance cross-presentation of cellular antigens and the generation of myeloma-specific killer T cells by dendritic cells. J Exp Med (2002) 195(1):125-33. doi:10.1084/jem.20011097

59. Moeller I, Spagnoli GC, Finke J, Veelken H, Houet L. Uptake routes of tumor-antigen MAGE-A3 by dendritic cells determine priming of naïve T-cell subtypes. Cancer Immunol Immunother (2012) 61(11):2079-90. doi:10.1007/ s00262-012-1272-y

60. Selenko N, Maidic O, Draxier S, Berer A, Jäger U, Knapp W, et al. CD20 antibody (C2B8)-induced apoptosis of lymphoma cells promotes phagocytosis by dendritic cells and cross-priming of CD8+ cytotoxic T cells. Leukemia (2001) 15(10):1619-26. doi:10.1038/sj.leu.2402226

61. Banerjee D, Matthews P, Matayeva E, Kaufman JL, Steinman RM, Dhodapkar KM. Enhanced T-cell responses to glioma cells coated with the antiEGF receptor antibody and targeted to activating FcgammaRs on human dendritic cells. J Immunother (2008) 31(2):113-20. doi:10.1097/CJI.0b013e31815a5892

62. Eissler N, Ruf P, Mysliwietz J, Lindhofer H, Mocikat R. Trifunctional bispecific antibodies induce tumor-specific $\mathrm{T}$ cells and elicit a vaccination effect. Cancer Res (2012) 72(16):3958-66. doi:10.1158/0008-5472.CAN-12-0146

63. Borg C, Jalil A, Laderach D, Maruyama K, Wakasugi H, Charrier S, et al. NK cell activation by dendritic cells (DCs) requires the formation of a synapse leading to IL-12 polarization in DCs. Blood (2004) 104(10):3267-75. doi:10.1182/blood-2004-01-0380

64. Lee SC, Srivastava RM, López-Albaitero A, Ferrone S, Ferris RL. Natural killer (NK): dendritic cell (DC) cross talk induced by therapeutic monoclonal antibody triggers tumor antigen-specific T cell immunity. Immunol Res (2011) 50(2-3):248-54. doi:10.1007/s12026-011-8231-0

65. Jaime-Ramirez AC, Mundy-Bosse BL, Kondadasula S, Jones NB, Roda JM, Mani A, et al. IL-12 enhances the antitumor actions of trastuzumab via NK cell IFN- $\gamma$ production. J Immunol (2011) 186(6):3401-9. doi:10.4049/ jimmunol.1000328

66. Pander J, Heusinkveld M, van der Straaten T, Jordanova ES, Baak-Pablo R, Gelderblom $\mathrm{H}$, et al. Activation of tumor-promoting type 2 macrophages by EGFR-targeting antibody cetuximab. Clin Cancer Res (2011) 17(17):5668-73. doi:10.1158/1078-0432.CCR-11-0239

67. Watanabe M, Wallace PK, Keler T, Deo YM, Akewanlop C, Hayes DF. Antibody dependent cellular phagocytosis (ADCP) and antibody dependent cellular cytotoxicity (ADCC) of breast cancer cells mediated by bispecific antibody, MDX-210. Breast Cancer Res Treat (1999) 53(3):199-207. doi:10. 1023/A:1006145507567
68. Manches O, Lui G, Chaperot L, Gressin R, Molens JP, Jacob MC, et al. In vitro mechanisms of action of rituximab on primary non-Hodgkin lymphomas. Blood (2003) 101(3):949-54. doi:10.1182/blood-2002-02-0469

69. Lefebvre ML, Krause SW, Salcedo M, Nardin A. Ex vivo-activated human macrophages kill chronic lymphocytic leukemia cells in the presence of rituximab: mechanism of antibody-dependent cellular cytotoxicity and impact of human serum. J Immunother (2006) 29(4):388-97. doi:10.1097/01. cji.0000203081.43235.d7

70. Leidi M, Gotti E, Bologna L, Miranda E, Rimoldi M, Sica A, et al. M2 macrophages phagocytose rituximab-opsonized leukemic targets more efficiently than $\mathrm{ml}$ cells in vitro. JImmunol (2009) 182(7):4415-22. doi:10.4049/ jimmunol.0713732

71. Shi Y, Fan X, Deng H, Brezski RJ, Rycyzyn M, Jordan RE, et al. Trastuzumab triggers phagocytic killing of high HER2 cancer cells in vitro and in vivo by interaction with Fcy receptors on macrophages. JImmunol (2015) 194(9):4379-86. doi:10.4049/jimmunol.1402891

72. Tipton TR, Roghanian A, Oldham RJ, Carter MJ, Cox KL, Mockridge CI, et al. Antigenic modulation limits the effector cell mechanisms employed by type I anti-CD20 monoclonal antibodies. Blood (2015) 125(12):1901-9. doi:10.1182/blood-2014-07-588376

73. Overdijk $M B$, Verploegen S, Bögels $M$, van Egmond $M$, Lammerts van Bueren JJ, Mutis T, et al. Antibody-mediated phagocytosis contributes to the anti-tumor activity of the therapeutic antibody daratumumab in lymphoma and multiple myeloma. MAbs (2015) 7(2):311-21. doi:10.1080/19420862.20 15.1007813

74. Uchida J, Hamaguchi Y, Oliver JA, Ravetch JV, Poe JC, Haas KM, et al. The innate mononuclear phagocyte network depletes B lymphocytes through $\mathrm{Fc}$ receptor-dependent mechanisms during anti-CD20 antibody immunotherapy. J Exp Med (2004) 199(12):1659-69. doi:10.1084/jem.20040119

75. Gong Q, Ou Q, Ye S, Lee WP, Cornelius J, Diehl L, et al. Importance of cellular microenvironment and circulatory dynamics in B cell immunotherapy. J Immunol (2005) 174(2):817-26. doi:10.4049/jimmunol.174.2.817

76. van der Bij GJ, Bögels M, Otten MA, Oosterling SJ, Kuppen PJ, Meijer S, et al. Experimentally induced liver metastases from colorectal cancer can be prevented by mononuclear phagocyte-mediated monoclonal antibody therapy. J Hepatol (2010) 53(4):677-85. doi:10.1016/j.jhep.2010.04.023

77. Montalvao F, Garcia Z, Celli S, Breart B, Deguine J, Van Rooijen N, et al. The mechanism of anti-CD20-mediated B cell depletion revealed by intravital imaging. J Clin Invest (2013) 123(12):5098-103. doi:10.1172/JCI70972

78. Noy R, Pollard JW. Tumor-associated macrophages: from mechanisms to therapy. Immunity (2014) 41(1):49-61. doi:10.1016/j.immuni.2014.06.010

79. Taskinen M, Karjalainen-Lindsberg ML, Nyman H, Eerola LM, Leppä S. A high tumor-associated macrophage content predicts favorable outcome in follicular lymphoma patients treated with rituximab and cyclophosphamidedoxorubicin-vincristine-prednisone. Clin Cancer Res (2007) 13(19):5784-9. doi:10.1158/1078-0432.CCR-07-0778

80. Kridel R, Xerri L, Gelas-Dore B, Tan K, Feugier P, Vawda A, et al. The prognostic impact of CD163-positive macrophages in follicular lymphoma: a study from the BC cancer agency and the lymphoma study association. Clin Cancer Res (2015) 21(15):3428-35. doi:10.1158/1078-0432.CCR14-3253

81. Barrio MM, Abes R, Colombo M, Pizzurro G, Boix C, Roberti MP, et al. Human macrophages and dendritic cells can equally present MART-1 antigen to $\mathrm{CD} 8^{+} \mathrm{T}$ cells after phagocytosis of gamma-irradiated melanoma cells. PLoS One (2012) 7(7):e40311. doi:10.1371/journal.pone.0040311

82. Di Gaetano N, Cittera E, Nota R, Vecchi A, Grieco V, Scanziani E, et al. Complement activation determines the therapeutic activity of rituximab in vivo. J Immunol (2003) 171(3):1581-7. doi:10.4049/jimmunol.171.3.1581

83. Wang SY, Weiner G. Complement and cellular cytotoxicity in antibody therapy of cancer. Expert Opin Biol Ther (2008) 8(6):759-68. doi:10.1517/14712598.8.6.759

84. Teeling JL, French RR, Cragg MS, van den Brakel J, Pluyter M, Huang H, et al. Characterization of new human CD20 monoclonal antibodies with potent cytolytic activity against non-Hodgkin lymphomas. Blood (2004) 104(6):1793-800. doi:10.1182/blood-2004-01-0039

85. Kroemer G, Galluzzi L, Kepp O, Zitvogel L. Immunogenic cell death in cancer therapy. Annu Rev Immunol (2013) 31:51-72. doi:10.1146/ annurev-immunol-032712-100008 
86. Pol J, Vacchelli E, Aranda F, Castoldi F, Eggermont A, Cremer I, et al. Trial watch: immunogenic cell death inducers for anticancer chemotherapy. Oncoimmunology (2015) 4(4):e1008866. doi:10.1080/21624 02X.2015.1008866

87. Baudino L, Sardini A, Ruseva MM, Fossati-Jimack L, Cook HT, Scott D, et al. C3 opsonization regulates endocytic handling of apoptotic cells resulting in enhanced T-cell responses to cargo-derived antigens. Proc Natl Acad Sci U S A (2014) 111(4):1503-8. doi:10.1073/pnas.1316877111

88. Kim PS, Armstrong TD, Song H, Wolpoe ME, Weiss V, Manning EA, et al. Antibody association with HER-2/neu-targeted vaccine enhances CD8 T cell responses in mice through Fc-mediated activation of DCs. J Clin Invest (2008) 118(5):1700-11. doi:10.1172/JCI34333

89. Knutson KL, Schiffman K, Disis ML. Immunization with a HER-2/neu helper peptide vaccine generates HER-2/neu CD8 T-cell immunity in cancer patients. J Clin Invest (2001) 107(4):477-84. doi:10.1172/JCI11752

90. Disis ML, Gooley TA, Rinn K, Davis D, Piepkorn M, Cheever MA, et al. Generation of T-cell immunity to the HER-2/neu protein after active immunization with HER-2/neu peptide-based vaccines. J Clin Oncol (2002) 20(11):2624-32. doi:10.1200/JCO.2002.06.171

91. Zehn D, Lee SY, Bevan MJ. Complete but curtailed T-cell response to very low-affinity antigen. Nature (2009) 458(7235):211-4. doi:10.1038/ nature 07657

92. Velthuis JH, Unger WW, Abreu JR, Duinkerken G, Franken K, Peakman M, et al. Simultaneous detection of circulating autoreactive CD8+ T-cells specific for different islet cell-associated epitopes using combinatorial MHC multimers. Diabetes (2010) 59(7):1721-30. doi:10.2337/db09-1486

93. Delluc S, Ravot G, Maillere B. Quantification of the preexisting CD4 T-cell repertoire specific for human erythropoietin reveals its immunogenicity potential. Blood (2010) 116(22):4542-5. doi:10.1182/blood-2010-04-280875

94. Enouz S, Carrié L, Merkler D, Bevan MJ, Zehn D. Autoreactive T cells bypass negative selection and respond to self-antigen stimulation during infection. J Exp Med (2012) 209(10):1769-79. doi:10.1084/jem.20120905

95. Su LF, Kidd BA, Han A, Kotzin JJ, Davis MM. Virus-specific CD4(+) memory-phenotype $\mathrm{T}$ cells are abundant in unexposed adults. Immunity (2013) 38(2):373-83. doi:10.1016/j.immuni.2012.10.021

96. Yu W, Jiang N, Ebert PJ, Kidd BA, Müller S, Lund PJ, et al. Clonal deletion prunes but does not eliminate self-specific $\alpha \beta$ CD8(+) T lymphocytes. Immunity (2015) 42(5):929-41. doi:10.1016/j.immuni.2015.05.001

97. Grube M, Rezvani K, Wiestner A, Fujiwara H, Sconocchia G, Melenhorst JJ, et al. Autoreactive, cytotoxic T lymphocytes specific for peptides derived from normal B-cell differentiation antigens in healthy individuals and patients with B-cell malignancies. Clin Cancer Res (2004) 10(3):1047-56. doi:10.1158/1078-0432.CCR-03-0075

98. Bae J, Martinson JA, Klingemann HG. Identification of CD19 and CD20 peptides for induction of antigen-specific CTLs against B-cell malignancies. Clin Cancer Res (2005) 11(4):1629-38. doi:10.1158/1078-0432.CCR-04-1612

99. Kowalewski DJ, Schuster H, Backert L, Berlin C, Kahn S, Kanz L, et al. HLA ligandome analysis identifies the underlying specificities of spontaneous antileukemia immune responses in chronic lymphocytic leukemia (CLL). Proc Natl Acad Sci U S A (2015) 112(2):E166-75. doi:10.1073/pnas.1416389112

100. Kumari S, Wälchli S, Fallang LE, Yang W, Lund-Johansen F, Schumacher TN, et al. Alloreactive cytotoxic T cells provide means to decipher the immunopeptidome and reveal a plethora of tumor-associated self-epitopes. Proc Natl Acad Sci U S A (2014) 111(1):403-8. doi:10.1073/pnas.1306549111

101. Afshar-Sterle S, Zotos D, Bernard NJ, Scherger AK, Rödling L, Alsop AE, et al. Fas ligand-mediated immune surveillance by $\mathrm{T}$ cells is essential for the control of spontaneous B cell lymphomas. Nat Med (2014) 20(3):283-90. doi:10.1038/nm.3442
102. Chaperot L, Manches O, Mi JQ, Moine A, Jacob MC, Gressin R, et al. Differentiation of anti-tumour cytotoxic $\mathrm{T}$ lymphocytes from autologous peripheral blood lymphocytes in non-Hodgkin's lymphomas. Br J Haematol (2002) 119(2):425-31. doi:10.1046/j.1365-2141.2002.03885.x

103. Timmerman JM, Czerwinski DK, Davis TA, Hsu FJ, Benike C, Hao ZM, et al. Idiotype-pulsed dendritic cell vaccination for B-cell lymphoma: clinical and immune responses in 35 patients. Blood (2002) 99(5):1517-26. doi:10.1182/ blood.V99.5.1517

104. Khodadoust MS, Olsson N, Wagar LE, Haabeth OA, Chen B, Swaminathan K, et al. Antigen presentation profiling reveals recognition of lymphoma immunoglobulin neoantigens. Nature (2017) 543(7647):723-7. doi:10.1038/ nature 21433

105. Garrido G, Rabasa A, Sánchez B, López MV, Blanco R, López A, et al. Induction of immunogenic apoptosis by blockade of epidermal growth factor receptor activation with a specific antibody. Jimmunol (2011) 187(10):4954-66. doi:10.4049/jimmunol.1003477

106. Cheadle EJ, Sidon L, Dovedi SJ, Melis MH, Alduaij W, Illidge TM, et al. The induction of immunogenic cell death by type II anti-CD20 monoclonal antibodies has mechanistic differences compared with type I rituximab. Br J Haematol (2013) 162(6):842-5. doi:10.1111/bjh.12427

107. Zhao T, Ren H, Wang X, Liu P, Yan F, Jiang W, et al. Rituximab-induced HMGB1 release is associated with inhibition of STAT3 activity in human diffuse large B-cell lymphoma. Oncotarget (2015) 6(29):27816-31. doi:10.18632/oncotarget.4816

108. Martinelli G, Schmitz SF, Utiger U, Cerny T, Hess U, Bassi S, et al. Longterm follow-up of patients with follicular lymphoma receiving single-agent rituximab at two different schedules in trial SAKK 35/98. J Clin Oncol (2010) 28(29):4480-4. doi:10.1200/JCO.2010.28.4786

109. Colombat P, Brousse N, Salles G, Morschhauser F, Brice P, Soubeyran P, et al. Rituximab induction immunotherapy for first-line low-tumor-burden follicular lymphoma: survival analyses with 7-year follow-up. Ann Oncol (2012) 23(9):2380-5. doi:10.1093/annonc/mds177

110. Bournazos S, Klein F, Pietzsch J, Seaman MS, Nussenzweig MC, Ravetch JV. Broadly neutralizing anti-HIV-1 antibodies require $\mathrm{Fc}$ effector functions for in vivo activity. Cell (2014) 158(6):1243-53. doi:10.1016/j. cell.2014.08.023

111. Pardoll DM. The blockade of immune checkpoints in cancer immunotherapy. Nat Rev Cancer (2012) 12(4):252-64. doi:10.1038/nrc3239

112. Marabelle A, Kohrt H, Levy R. New insights into the mechanism of action of immune checkpoint antibodies. Oncoimmunology (2014) 3(8):e954869. doi: 10.4161/21624011.2014.954869

113. Buchegger F, Larson SM, Mach JP, Chalandon Y, Dietrich PY, Cairoli A, et al. Radioimmunotherapy combined with maintenance anti-CD20 antibody may trigger long-term protective $\mathrm{T}$ cell immunity in follicular lymphoma patients. Clin Dev Immunol (2013) 2013:875343. doi:10.1155/ $2013 / 875343$

Conflict of Interest Statement: The authors declare that the research was conducted in the absence of any commercial or financial relationships that could be construed as a potential conflict of interest.

Copyright (C) 2017 Deligne, Milcent, Josseaume, Teillaud and Sibéril. This is an open-access article distributed under the terms of the Creative Commons Attribution License (CC BY). The use, distribution or reproduction in other forums is permitted, provided the original author(s) or licensor are credited and that the original publication in this journal is cited, in accordance with accepted academic practice. No use, distribution or reproduction is permitted which does not comply with these terms. 